\title{
Calculation and Visualization of Flexion and Skewness
}

\section{Krisztián KERKOVITS}

Department of Cartography and Geoinformatics, Eötvös Loránd University, Budapest

kerkovits@map.elte.hu

Abstract. A recent study on map projections expanded two new measures of distortion, namely flexion and skewness. However, it introduced them only for the unit sphere. The present paper derives formulas for the rotational ellipsoid and demonstrates that these kinds of distortion always have a unit of measurement. A new method of illustration is described, by which these quantities can be visualized in an expressive way.

Keywords: map projections, distortion, flexion and skewness, visualization

\section{Non-affine Kinds of Distortion in Map Projections}

The theory of distortions in map projections is based on Tissot's theorems (1878), which state the following, among other things, in a somewhat simplified form:

- Any projection can be considered the result of local affine transformations

- The image of an infinitesimal circle on any twice differentiable surface will be an infinitesimal ellipse after being mapped by a twice differentiable mapping.

Though many studies published recently acknowledge that the image of infinitesimal objects suffers only affine kinds of distortion, the map-user reads finite objects from the map to which these theorems do not apply. Most researchers, such as Fisher \& Miller (1944), Tobler (1964), Peters (1975), Laskowski (1997), Canters (2002), and Gott, Mugnolo \& Colley (2007) have tried to highlight the non-affine properties of map projections by analysing the image of different finite-sized objects on the projected plane. This progressively developed method is meant to generate random objects in large quantities on the reference frame and compare their images to the original shapes using statistical methods.
As a consequence of random generation, this process cannot be reproduced. Furthermore, as Laskowski (1997) noted, the distribution of generated objects at the map edge is not as dense as in the centre. Albinus (1981) noted that the use of the method in the vicinity of the discontinuities raises problems of interpretation.

Goldberg and Gott (2007) pointed out that it is not necessary to examine objects of finite size to investigate the non-affine properties of a projection, because they can be detected in the infinitesimal vicinity of a single point. They defined two new quantities, called flexion and skewness. The formulas in their original article are expressed using tensor calculus and inverse projection formulas, so their practical calculation is extremely cumbersome. The analysed points are still obtained by random number generators. Their formulas can only be applied to a unit sphere.

In the following, formulas are derived that are easier to use in practice and do not require the calculation of inverse projection formulas. It is noted that flexion and skewness always have a unit of measurement. This paper shows how these quantities can be visualized. The definitions are extended for an ellipsoid of revolution. Finally, the need to generate random points is eliminated in order to make the calculations reproducible. 


\section{Računanje i vizualizacija fleksije i asimetrije}

Krisztián KERKOVITS

Odjel za kartografiju i geoinformatiku, Sveučilište Eötvös Loránd, Budimpešta kerkovits@map.elte.hu

Sažetak. Nedavnom studijom o kartografskim projekcijama uvedene su dvije nove mjere distorzije: fleksija i asimetrija. Međutim, uvedena je samo za jediničnu sferu. U ovom su radu izvedene formule za rotacijski elipsoid i pokazuje se da tim mjerama distorzije odgovaraju mjerne jedinice. Opisana je nova metoda vizualizacije s pomoću koje se te veličine mogu prikazati na izražajan način.

Ključne riječi: kartografske projekcije, distorzija, fleksija i asimetrija, vizualizacija

\section{Neafini tipovi distorzije pri kartografskim projekcijama}

Teorija distorzija kod kartografskih projekcija temelji se na Tissotovim teoremima (1878) koji, između ostalog, u donekle pojednostavljenom obliku, tvrde sljedeće:

- Svaka se projekcija može smatrati rezultatom lokalnih afinih transformacija.

- Slika infinitezimalno male kružnice bit će infinitezimalno mala elipsa pri dvostruko diferencijabilnom preslikavanju.

Premda brojne nedavno objavljene studije potvrđuju da slika infinitezimalnih objekata pokazuje samo afine tipove distorzije, korisnik karte čita konačne objekte $\mathrm{s}$ karte na koje ti teoremi nisu primjenjivi. Većina istraživača kao što su Fisher i Miller (1944), Tobler (1964), Peters (1975), Laskowski (1997), Canters (2002) te Gott, Mugnolo i Colley (2007) pokušava istaknuti neafina svojstva kartografskih projekcija analizom slike različitih objekata konačnih veličina u ravnini projekcije. Riječ je o metodi koja stvara velik broj slučajnih objekata na referentnoj plohi i s pomoću statističkih metoda uspoređuje njihove slike s izvornim oblicima.
Kao posljedica slučajnog generiranja, takav se postupak ne može ponoviti. Nadalje, kao što je uočio Laskowski (1997), distribucija generiranih objekata na rubovima karte nije iste gustoće kao u središtu karte. Albinus (1981) je uočio da upotreba metode u blizini diskontinuiteta stvara probleme kod interpretacije.

Goldberg i Gott (2007) istaknuli su da nije nužno istraživati objekte konačnih veličina da bi se istražila neafina svojstva projekcije jer se ona mogu otkriti u infinitezimalnoj okolini pojedine točke. Definirali su dvije nove veličine koje su nazvali fleksija i asimetrija. Formule u njihovom izvornom članku izražene su upotrebom tenzorskog računa i formulama inverzne projekcije pa je njihovo praktično računanje izuzetno nezgrapno. Analizirane točke ipak se dobivaju generatorima slučajnih brojeva. Njihove se formule mogu primijeniti samo na jediničnu sferu.

U nastavku su izvedene formule koje su praktično korisnije i ne zahtijevaju izračunavanje inverznih projekcijskih formula. Napominjemo da fleksija i asimetrija uvijek imaju mjernu jedinicu. Ovaj rad pokazuje kako se te veličine mogu vizualizirati. Definicije su proširene na rotacijski elipsoid. Konačno, potreba za generiranjem slučajnih točaka eliminirana je kako bi se računanja mogla ponoviti. 


\section{Traditional Measures of Distortion}

The linear scale is the limit of the ratio between the corresponding $\mathrm{d} t^{\prime}$ infinitesimal distance on the map and the $\mathrm{d} t$ distance on the reference surface in a mapping described by the functions $x[\varphi(t), \lambda(t)]$ and $y[\varphi(t), \lambda(t)]$ - where $x$ and $y$ are measured in a unit scale and $\varphi(t)$ and $\lambda(t)$ are the parametric form of a geodesic line parameterised by the distance $t-$ as $\mathrm{d} t$ approaches zero:

$$
l=\frac{\mathrm{d} t^{\prime}}{\mathrm{d} t}=\sqrt{\left(\frac{\mathrm{d} x}{\mathrm{~d} t}\right)^{2}+\left(\frac{\mathrm{d} y}{\mathrm{~d} t}\right)^{2}}
$$

This is expressed as a function of latitude $\varphi$, longitude $\lambda$, and starting azimuth $\alpha$ measured eastwards from the geographical North on a sphere with radius $R$ (Canters 2002):

$$
\begin{aligned}
& l^{2}=\left[\left(\frac{\partial x}{\partial \varphi}\right)^{2}+\left(\frac{\partial y}{\partial \varphi}\right)^{2}\right] \frac{\cos ^{2} \alpha}{R^{2}}+ \\
& +\left[\left(\frac{\partial x}{\partial \lambda}\right)^{2}+\left(\frac{\partial y}{\partial \lambda}\right)^{2}\right] \frac{\sin ^{2} \alpha}{R^{2} \cos ^{2} \varphi}+ \\
& +2\left[\frac{\partial x}{\partial \varphi} \frac{\partial x}{\partial \lambda}+\frac{\partial y}{\partial \varphi} \frac{\partial y}{\partial \lambda}\right] \frac{\sin \alpha \cos \alpha}{R^{2} \cos \varphi}
\end{aligned}
$$

Tissot's theorems show that differentiable projections depict any infinitesimal circle as an infinitesimal ellipse. The semi-axes $a$ and $b$ of this ellipse are also the extreme values of the linear scale; their calculation can be found in Snyder's book (1987).

The linear scale is a proportion; it has no unit of measurement and no dimension. The sequential application of projections that have linear scales $l_{1}$ and $l_{2}$ in a given point and direction respectively results in a linear scale of $l_{1} l_{2}$. From there, the linear scale has a multiplicative nature, as the result of the combination is not a sum but a product.

The concept of areal scale is introduced in a similar manner by means of the infinitesimal areas $\mathrm{d} S$ on the reference frame and $d S^{\prime}$ on the map:

$$
p=\frac{\mathrm{d} S^{\prime}}{\mathrm{d} S}=a b
$$

As and $a$ and $b$ are dimensionless and measured on a ratio scale, $p$ is consequently also dimensionless.

The angular distortion is the ratio between the tangents of the angles $\vartheta^{\prime}$ on the map and $\vartheta$ on the reference frame. If one of the arms coincides with the direction of the maximum linear scale, then for another arbitrary arm:

$$
i=\frac{\tan \vartheta^{\prime}}{\tan \vartheta}=\frac{b}{a}
$$

There are many methods for depicting distortions (Mulcahy \& Clarke 2001), however, only two are used frequently. Distortion isocols use the method of isolines. In order to display values in an expressive way, it is possible to show quantities derived from these distortions. It is easy to understand the deviation of $p$ from 1 expressed in \% in the case of areal scale, and the maximum angular deviation in the case of angular distortion:

$$
\omega=2 \arcsin \frac{a-b}{a+b}
$$

As the linear scale usually depends on the direction, it can be represented by the diagram method. This is known as Tissot's indicatrix (Tissot 1878). The diagram is an ellipse whose radius is proportional to the linear scale in the corresponding direction. The area of the ellipse depicts areal distortion and its flattening reflects angular distortion. Here, the state without distortion is depicted by a circle drawn onto the ellipse, as the magnitude of the linear and areal scales cannot be read from Tissot's indicatrices alone. Tissot's indicatrices are shown in red in Figure 1.

\section{Skewness and Flexion}

Skewness indicates that how much the linear scale $l$ in the direction $\alpha$ changes when taking a small $\mathrm{d} t$ distance on a geodesic with azimuth:

$$
s=\frac{1}{l} \frac{\mathrm{d} l}{\mathrm{~d} t}
$$

It is clear that $s=0$ along the lines of constant linear scale. It is impossible to obtain a projection in which $s=0$ in every point and direction, because this would mean that the linear scale was constant at all points and directions. Then, by choosing a corresponding map scale, a distortion-free projection would be obtained.

Flexion expresses the perpendicular component. Now the issue is how much $\mathrm{d} \alpha^{\prime}$ angular turn (in radians) is taken on the map while going $\mathrm{d} t$ distance on a geodetic line with $\alpha$ starting azimuth:

$$
f=\frac{\mathrm{d} \alpha^{\prime}}{\mathrm{d} t}
$$

It appears from the definition that if a geodesic line is mapped to a straight line, then $f$ is zero along the geodesic. In addition, if a spherical geodesic line is mapped to an equidistant whole circle (not just a circular arc), then $f=1 / R$ along this line. Although no projection can be obtained without skewness, it is possible to completely eliminate flexion, but only for a sphere and areas smaller than a hemisphere. This is due to the fact that among known projections, only the spherical 


\section{Tradicionalne mjere distorzije}

Linearno mjerilo je granična vrijednost kvocijenta infinitezimalne udaljenosti na karti $\mathrm{d} t t^{\prime} \mathrm{i}$ udaljenosti $\mathrm{d} t$ na referentnoj plohi pri preslikavanju definiranom funkcijama $x[\varphi(t), \lambda(t)]$ i $y[\varphi(t), \lambda(t)]$, gdje su $x$ i $y$ mjereni $u$ jediničnom mjerilu, a $\varphi(t), \lambda(t)$ parametarski oblik geodetske linije parametrizirane udaljenošću $t \mathrm{kad} d t$ teži prema nuli:

$$
l=\frac{\mathrm{d} t^{\prime}}{\mathrm{d} t}=\sqrt{\left(\frac{\mathrm{d} x}{\mathrm{~d} t}\right)^{2}+\left(\frac{\mathrm{d} y}{\mathrm{~d} t}\right)^{2}}
$$

Izraženo s pomoću geografske širine $\varphi$, dužine $\lambda \mathrm{i}$ azimuta $\alpha$ mjerenog istočno od Sjevernoga pola na sferi polumjera $R$ (Canters 2002):

$$
\begin{aligned}
& l^{2}=\left[\left(\frac{\partial x}{\partial \varphi}\right)^{2}+\left(\frac{\partial y}{\partial \varphi}\right)^{2}\right] \frac{\cos ^{2} \alpha}{R^{2}}+ \\
& +\left[\left(\frac{\partial x}{\partial \lambda}\right)^{2}+\left(\frac{\partial y}{\partial \lambda}\right)^{2}\right] \frac{\sin ^{2} \alpha}{R^{2} \cos ^{2} \varphi}+ \\
& 2\left[\frac{\partial x}{\partial \varphi} \frac{\partial x}{\partial \lambda}+\frac{\partial y}{\partial \varphi} \frac{\partial y}{\partial \lambda}\right] \frac{\sin \alpha \cos \alpha}{R^{2} \cos \varphi}
\end{aligned}
$$

Tissotovi teoremi pokazuju da diferencijabilne projekcije prikazuju bilo koju infinitezimalnu kružnicu u infinitezimalnu elipsu. Poluosi $a$ i $b$ te elipse su također ekstremne vrijednosti linearnog mjerila, a njihovo se računanje može naći u Snyderovoj knjizi (1987).

Linearno mjerilo je omjer, nema mjerne jedinice ni dimenzije. Sekvencijalna primjena projekcija koje imaju linearna mjerila $l_{1} \mathrm{i} l_{2} \mathrm{u}$ danoj točki i smjeru daje linearno mjerilo $l_{1} l_{2}$. Dakle, linearno mjerilo je multiplikativne prirode jer rezultat kompozicije nije zbroj mjerila, nego njihov umnožak.

Koncept površinskog mjerila uvodi se na sličan način s pomoću infinitezimalnih površina dS na referentnoj plohi i dS' na karti:

$$
p=\frac{\mathrm{d} S^{\prime}}{\mathrm{d} S}=a b
$$

Budući da su $a$ i $b$ bez dimenzija, i $p$ je prema tome bez dimenzija.

Kutna distorzija je kvocijent između tangesa kutova na karti i na referentnoj plohi $\vartheta^{\prime}$ i $\vartheta$. Ako se jedan krak kuta poklapa sa smjerom maksimalnog linearnog mjerila, tada za proizvoljan drugi krak vrijedi:

$$
i=\frac{\tan \vartheta^{\prime}}{\tan \vartheta}=\frac{b}{a}
$$

Postoji mnogo metoda za prikaz distorzija (Mulcahy i Clarke 2001), međutim, često se koriste samo dvije. Izokole distorzije temelje se na metodi izolinija. Da bi se vrijednosti izrazile što istaknutije, moguće je prikazati izvedene vrijednosti iz tih distorzija. Lako je razumjeti odstupanje $p$ od 1 izraženo u postotcima za površinsko mjerilo i maksimalno kutno odstupanje u slučaju distorzije kutova:

$$
\omega=2 \arcsin \frac{a-b}{a+b}
$$

Budući da linearno mjerilo obično ovisi o smjeru, može se prikazati metodom dijagrama. To je poznato kao Tissotova indikatrisa (Tissot 1878). Dijagram je elipse čiji je polumjer proprocionalan linearnom mjerilu u odgovarajućem smjeru. Površina elipse prikazuje distorziju površina, a njezina spljoštenost odgovara kutnoj distorziji. Budući da se veličine linearnog i površinskog mjerila ne mogu pročitati samo iz Tissotovih indikatrisa, stanje bez distorzije može se prikazati s pomoću kružnice nacrtane preko elipse. Tissotove indikatrise prikazane su crveno na slici 1.

\section{Asimetrija i fleksija}

Asimetrija upućuje na to kako se linearno mjerilo $l$ mijenja u smjeru $\alpha$ kad se uzme mala udaljenost $d t u z-$ duž geodetske linije po azimutu $\alpha$ :

$$
s=\frac{1}{l} \frac{\mathrm{d} l}{\mathrm{~d} t}(6)
$$

Jasno je da je $s=0$ uzduž linija konstantnog linearnog mjerila. Nemoguće je dobiti projekciju kod koje bi bilo $s=0$ u svakoj točki i smjeru jer bi to značilo da je linearno mjerilo konstantno u svim točkama i smjerovima. Tada bi se izborom odgovarajućeg mjerila karte dobila projekcija bez distorzija.

Fleksija izražava komponentu okomitosti. Pitanje je koliko će iznositi kutni zaokret $d \alpha^{\prime}$ (u radijanima) na karti kad se kreće po geodetskoj liniji za vrijednost $\mathrm{d} t \mathrm{u}$ smjeru početnog azimuta $\alpha$ :

$$
f=\frac{\mathrm{d} \alpha^{\prime}}{\mathrm{d} t}(7)
$$

Iz definicije slijedi da, ako se geodetska linija preslika kao pravac, tada će $f$ biti jednako nulio uzduž te linije. Uz to, ako se preslikava geodetska linija sa sfere u ekvidistantnu punu kružnicu (ne samo kružni luk), tada je uzduž te linije $f=1 / R$. Iako se nijedna projekcija ne može dobiti bez asimetrije, fleksiju je moguće u potpunosti eliminirati, no samo za sferu i samo za područja manja od hemisfere. To je posljedica činjenice da se među svim 
gnomonic maps all geodesics to straight lines. However this is an azimuthal projection where all (meta) parallels are circles, and so would be the image of the (meta) Equator. It has been stated that in such cases $f=1 / R$, hence the (meta) Equator can no longer be depicted without flexion.

The definitions of Goldberg and Gott (2007) are equivalent to formulas (6) and (7); however, the original definitions were expressed in a different form using scalar or cross products of vectors.

The $l$ linear scale is a proportion and, therefore, dimensionless. However, the differentials here are the dimensionless linear scale or angular turn respectively, divided by a distance. Consequently, $s$ and $f$ do have a dimension, and it is 1 / distance. They also have unit of measurement. Goldberg and Gott (2007) did not notice this: in their articles any numerical values should be understood with a unit of 1 / Earth radius. For the sake of expressiveness, the unit of measurement $\% / 1000 \mathrm{~km}$ is proposed for measuring skewness and ${ }^{\circ} / 1000 \mathrm{~km}$ for flexion.

It can be stated that $s$ and $f$ do not have a multiplicative but rather an additive nature. If the linear scale of a projection at a given point and direction is $l_{1}$, its skewness is $s_{1}$, in another projection the same values are $l_{2}$ and $s_{2}$, the linear scales of these two projections in a small distance $\mathrm{d} t$ are $l_{1}\left(1+s_{1} \mathrm{~d} t\right)$ and $l_{2}\left(1+s_{2} \mathrm{~d} t\right)$ respectively. Due to the multiplicative nature of the linear scale, after successive application of these projections, the new linear scale is $l_{1} l_{2}$ in the original point and direction, and in $\mathrm{d} t$ distance it is

$$
l_{1} l_{2}\left(1+s_{1} \mathrm{~d} t+s_{2} \mathrm{~d} t+s_{1} s_{2} \mathrm{~d} t^{2}\right) .
$$

As a result of (6), the new skewness is $s_{1}+s_{2}$, so it is not understood as an exponential measure like the linear scale. A similar proof can be considered in an analogous way for $f$.

\section{Practical Calculation and Properties}

For the practical calculation of the differentials, let the right side of equation (1) obtained for the linear scale be substituted for $l$ in equation (6):

$$
s=\frac{1}{l} \frac{2 \frac{\mathrm{d}^{2} x}{\mathrm{~d} t^{2}} \frac{\mathrm{d} x}{\mathrm{~d} t}+2 \frac{\mathrm{d}^{2} y}{\mathrm{~d} t^{2}} \frac{\mathrm{d} y}{\mathrm{~d} t}}{2 \sqrt{\left(\frac{\mathrm{d} x}{\mathrm{~d} t}\right)^{2}+\left(\frac{\mathrm{d} y}{\mathrm{~d} t}\right)^{2}}}=\frac{\frac{\mathrm{d} x}{\mathrm{~d} t} \frac{\mathrm{d}^{2} x}{\mathrm{~d} t^{2}}+\frac{\mathrm{d} y}{\mathrm{~d} t} \frac{\mathrm{d}^{2} y}{\mathrm{~d} t^{2}}}{l^{2}}
$$

According to the most accepted definition, the $\kappa$ curvature of a curve is the differential of the tangent direction $\alpha^{\prime}$ with respect to the map distance $d t^{\prime}$. However, the calculation of flexion requires the differential with respect to the distance $\mathrm{d} t$ on the reference frame. Using the chain rule:

$$
f=\frac{\mathrm{d} \alpha^{\prime}}{\mathrm{d} t^{\prime}} \frac{\mathrm{d} t^{\prime}}{\mathrm{d} t}=\kappa l
$$

If the parametric form of curvature (Stoker 1989) is substituted for $\kappa$ by using the distance on the reference surface as a parameter, one can get:

$$
f=l \frac{\frac{\mathrm{d} x}{\mathrm{~d} t} \frac{\mathrm{d}^{2} y}{\mathrm{~d} t^{2}}-\frac{\mathrm{d} y}{\mathrm{~d} t} \frac{\mathrm{d}^{2} x}{\mathrm{~d} t^{2}}}{\left[\left(\frac{\mathrm{d} x}{\mathrm{~d} t}\right)^{2}+\left(\frac{\mathrm{d} y}{\mathrm{~d} t}\right)^{2}\right]^{3 / 2}}=\frac{\frac{\mathrm{d} x}{\mathrm{~d} t} \frac{\mathrm{d}^{2} y}{\mathrm{~d} t^{2}}-\frac{\mathrm{d} y}{\mathrm{~d} t} \frac{\mathrm{d}^{2} x}{\mathrm{~d} t^{2}}}{l^{2}}
$$

$f$ and $s$ can also be expressed by means of the initial point $\varphi, \lambda$ and the spherical starting azimuth $\alpha$. To calculate results, the bivariate chain rule is applied, and the corresponding well-known spherical identities are substituted for derivatives like $\mathrm{d} \varphi / \mathrm{d} t$ :

$$
\begin{aligned}
& \frac{\mathrm{d} x}{\mathrm{~d} t}=\frac{\partial x}{\partial \varphi} \frac{\cos \alpha}{R}+\frac{\partial x}{\partial \lambda} \frac{\sin \alpha}{R \cos \varphi} \\
& \frac{\mathrm{d} y}{\mathrm{~d} t}=\frac{\partial y}{\partial \varphi} \frac{\cos \alpha}{R}+\frac{\partial y}{\partial \lambda} \frac{\sin \alpha}{R \cos \varphi}
\end{aligned}
$$

$$
\frac{\mathrm{d}^{2} x}{\mathrm{~d} t^{2}}=-\frac{\partial x}{\partial \varphi} \frac{\tan \varphi \sin ^{2} \alpha}{R^{2}}+\frac{\partial x}{\partial \lambda} \frac{2 \tan \varphi \sin \alpha \cos \alpha}{R^{2} \cos \varphi}+
$$

$+\frac{\partial^{2} x}{\partial \varphi^{2}} \frac{\cos ^{2} \alpha}{R^{2}}+\frac{\partial^{2} x}{\partial \lambda^{2}} \frac{\sin ^{2} \alpha}{R^{2} \cos ^{2} \varphi}+2 \frac{\partial^{2} x}{\partial \varphi \partial \lambda} \frac{\cos \alpha \sin \alpha}{R^{2} \cos \varphi}$

$$
\begin{gathered}
\frac{\mathrm{d}^{2} y}{\mathrm{~d} t^{2}}=-\frac{\partial y}{\partial \varphi} \frac{\tan \varphi \sin ^{2} \alpha}{R^{2}}+\frac{\partial y}{\partial \lambda} \frac{2 \tan \varphi \sin \alpha \cos \alpha}{R^{2} \cos \varphi}+ \\
+\frac{\partial^{2} y}{\partial \varphi^{2}} \frac{\cos ^{2} \alpha}{R^{2}}+\frac{\partial^{2} y}{\partial \lambda^{2}} \frac{\sin ^{2} \alpha}{R^{2} \cos ^{2} \varphi}+2 \frac{\partial^{2} y}{\partial \varphi \partial \lambda} \frac{\cos \alpha \sin \alpha}{R^{2} \cos \varphi}
\end{gathered}
$$

where the partial derivatives are known functions of $\varphi$ and $\lambda$.

Goldberg and Gott (2007) described a far more complicated method of computation, which requires obtaining inverse projection formulas and calculating Christoffel symbols. In contrast, partial derivatives in the formulas described here can be approximated by a numerical method, and calculation can be performed easily.

An easy way to see the property of these kinds of distortion is as follows; if the projection formulas are 
poznatim projekcijama, samo kod sferne gnomonske projekcije sve geodetske linije preslikavaju $u$ pravce. Međutim, to je azimutna projekcija pri kojoj su sve (meta)paralele kružnice, pa će tako biti i sa slikom (meta)ekvatora. Rečeno je da je u takvim slučajevima $f=1 / R$ te stoga (meta)ekvator ne može biti prikazan bez fleksije.

Definicije Goldberga i Gotta (2007) ekvivalente su formulama (6) i (7). Međutim, izvorne definicije izražene su u drukčijem obliku upotrebom slakarnog i vektorskog produkta vektora.

Linearno mjerilo $l$ je omjer i stoga bezdimenzionalno. Međutim, diferencijali su ovdje bezdimenzionalno linearno mjerilo, odnosno kutni zakret, podijeljeni s udaljenošću. Prema tome, $s$ i $f$ imaju dimenziju i ona je 1/udaljenost. Oni također imaju mjerne jedinice. Goldberg i Gott (2007) to nisu uočili, u njihovu članku sve numeričke vrijednosti treba razumjeti $u$ jedinicama 1/Zemljin polumjer. Radi izražajnosti, predlaže se mjerna jedinica $\% / 1000 \mathrm{~km}$ za asimetriju i $\% / 1000 \mathrm{~km}$ za fleksiju.

Može se reći da s i f nisu multiplikativne, nego aditivne prirode. Ako je linearno mjerilo neke projekcije $u$ danoj točki i smjeru $l_{1}$, a asimetrija $s_{1}$, u nekoj su drugoj projekciji te vrijednosti $l_{2} i s_{2}$, a linearna mjerila tih dviju projekcija na maloj udaljenosti $\mathrm{d} t$ su $l_{1}\left(1+s_{1} \mathrm{~d} t\right)$, odnosno $l_{2}\left(1+s_{2} \mathrm{~d} t\right)$. Zbog multiplikativne prirode linearnog mjerila, sukcesivnim primjenama tih projekcija, novo linearno mjerilo bit će $l_{1} l_{2} u$ originalnoj točki i smjeru, a na udaljenosti $d t$ bit će

$$
l_{1} l_{2}\left(1+s_{1} \mathrm{~d} t+s_{2} \mathrm{~d} t+s_{1} s_{2} \mathrm{~d} t^{2}\right) .
$$

Kao posljedica (6), nova asimetrija bit će $s_{1}+s_{2}$, dakle nije eksponencijalna mjera kao što je linearno mjerilo. sličan se dokaz na analogan način može provesti za $f$.

\section{Praktično računanje i svojstva}

Za praktično računanje diferencijala uvrstimo jednadžbu (1) dobivenu za linearno mjerilo $l u$ (6):

$$
s=\frac{1}{l} \frac{2 \frac{\mathrm{d}^{2} x}{\mathrm{~d} t^{2}} \frac{\mathrm{d} x}{\mathrm{~d} t}+2 \frac{\mathrm{d}^{2} y}{\mathrm{~d} t^{2}} \frac{\mathrm{d} y}{\mathrm{~d} t}}{2 \sqrt{\left(\frac{\mathrm{d} x}{\mathrm{~d} t}\right)^{2}+\left(\frac{\mathrm{d} y}{\mathrm{~d} t}\right)^{2}}}=\frac{\frac{\mathrm{d} x}{\mathrm{~d} t} \frac{\mathrm{d}^{2} x}{\mathrm{~d} t^{2}}+\frac{\mathrm{d} y}{\mathrm{~d} t} \frac{\mathrm{d}^{2} y}{\mathrm{~d} t^{2}}}{l^{2}}
$$

Zakrivljenost $\kappa$ krivulje definira se kao diferencijal tangencijalnog smjera $\alpha^{\prime}$ s obzirom na udaljenost na karti dt'. Međutim, računanje fleksije zahtijeva diferencijal s obzirom na udaljenost $\mathrm{d} t$ na referentnoj plohi. Upotrebom lančanog pravila:

$$
f=\frac{\mathrm{d} \alpha^{\prime}}{\mathrm{d} t^{\prime}} \frac{\mathrm{d} t^{\prime}}{\mathrm{d} t}=\kappa l
$$

Ako se parametarski oblik zakrivljenosti (Stoker 1989) uvrsti za к upotrebom udaljenosti na referentnoj plohi kao parametrom, dobije se:

$$
f=l \frac{\frac{\mathrm{d} x}{\mathrm{~d} t} \frac{\mathrm{d}^{2} y}{\mathrm{~d} t^{2}}-\frac{\mathrm{d} y}{\mathrm{~d} t} \frac{\mathrm{d}^{2} x}{\mathrm{~d} t^{2}}}{\left[\left(\frac{\mathrm{d} x}{\mathrm{~d} t}\right)^{2}+\left(\frac{\mathrm{d} y}{\mathrm{~d} t}\right)^{2}\right]^{3 / 2}}=\frac{\frac{\mathrm{d} x}{\mathrm{~d} t} \frac{\mathrm{d}^{2} y}{\mathrm{~d} t^{2}}-\frac{\mathrm{d} y}{\mathrm{~d} t} \frac{\mathrm{d}^{2} x}{\mathrm{~d} t^{2}}}{l^{2}}
$$

Vrijednosti funkcija $f$ i $s$ mogu se također izraziti s pomoću $\varphi, \lambda$ početne točke i polaznog azimuta $\alpha$ na sferi. Da bi se došlo do rezultata, primijenimo lančano pravilo za deriviranje i uvrstimo odgovarajuće dobro poznate sferne identite za derivacije, kao npr. za $\mathrm{d} \varphi / \mathrm{d} t$ :

$$
\begin{aligned}
& \frac{\mathrm{d} x}{\mathrm{~d} t}=\frac{\partial x}{\partial \varphi} \frac{\cos \alpha}{R}+\frac{\partial x}{\partial \lambda} \frac{\sin \alpha}{R \cos \varphi} \\
& \frac{\mathrm{d} y}{\mathrm{~d} t}=\frac{\partial y}{\partial \varphi} \frac{\cos \alpha}{R}+\frac{\partial y}{\partial \lambda} \frac{\sin \alpha}{R \cos \varphi}
\end{aligned}
$$

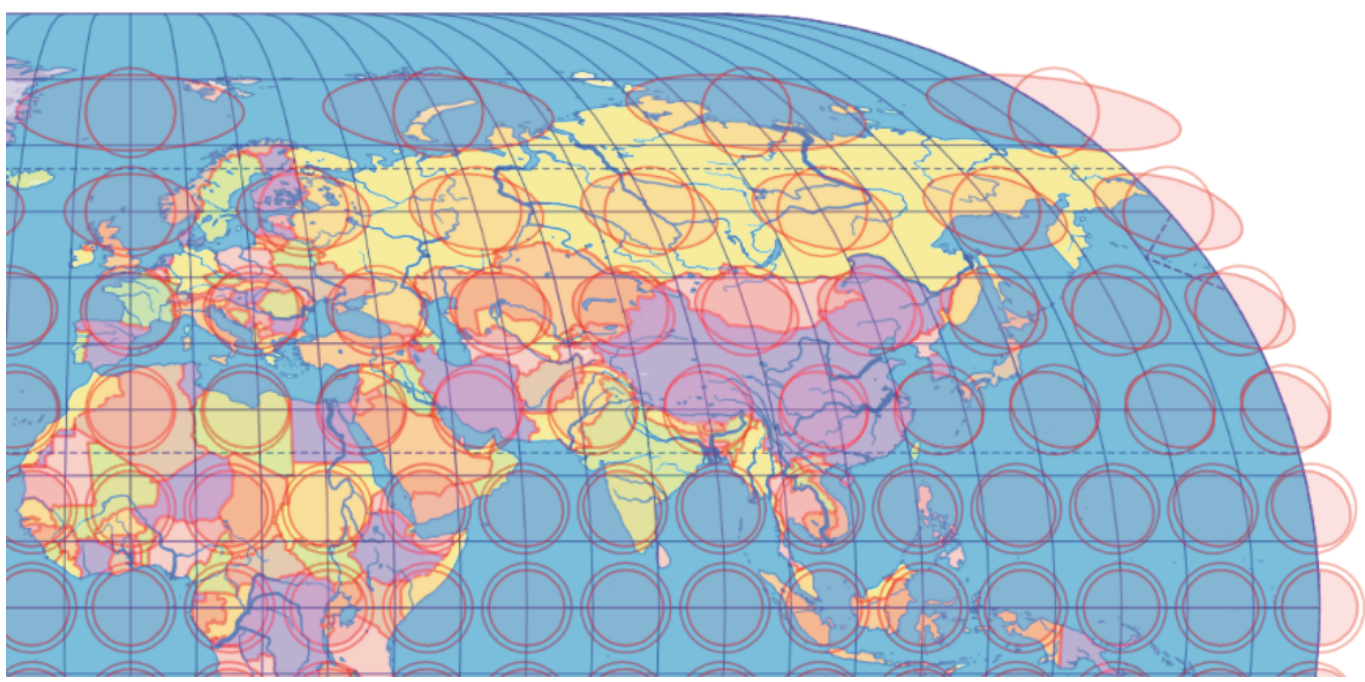

Fig. 1 Tissot's indicatrices in the Eckert III projection Slika 1. Tissotove indikatrise $u$ Eckertovoj III projekciji 
twice differentiable, then

$$
\begin{aligned}
& f(\varphi, \lambda, \alpha)=-f(\varphi, \lambda, \alpha+\pi) \text { and } \\
& s(\varphi, \lambda, \alpha)=-s(\varphi, \lambda, \alpha+\pi) \quad(15)
\end{aligned}
$$

By applying formulas (8) and (10), a relationship between flexion, skewness, and the second derivative of projection formulas can be obtained:

$$
l \sqrt{f^{2}+s^{2}}=\sqrt{\left(\frac{\mathrm{d}^{2} x}{\mathrm{~d} t^{2}}\right)^{2}+\left(\frac{\mathrm{d}^{2} y}{\mathrm{~d} t^{2}}\right)^{2}}
$$

This formula is visualised in Figure 2 using the denotation

$$
1=\left(\frac{\mathrm{d} x}{\mathrm{~d} t} ; \frac{\mathrm{d} y}{\mathrm{~d} t}\right)
$$

where the squared sum of flexion and skewness is equal to the square of the second derivative of the projection as a vector marked in orange - normalized by the linear scale.

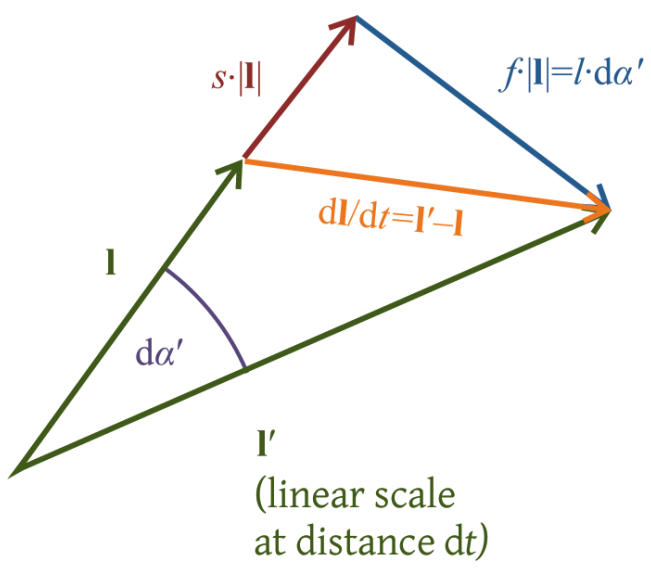

Fig. 2 Descriptive meaning of flexion and skewness

An important feature of these measures is that they are invariant under similarity transformations made to the projection.

Distortion-free lines or points may also be interpreted in terms of flexion and skewness:

- In equidistant, equal-area, and conformal cylindrical projections, the Equator shows no flexion and skewness.

- There is no flexion and skewness at one of the poles when using equidistant, equal-area, or conformal azimuthal projections.

- Among conic projections with one standard parallel, the equidistant and equal-area mappings with poleline and the conformal one with pole-point result in no flexion and skewness along their standard parallel. However, there are presumably no parallels without flexion and skewness in equidistant and equal-area conic projections with pole-point or two standard parallels.

\section{Visualization of Flexion and Skewness}

Although Goldberg and Gott (2007) developed a visualization method to depict flexion and skewness, they did so by mapping finite shapes, showing the effects of these distortions in an indirect way. The deformation indicatrix demonstrated below provides an opportunity for direct visualization. The deformation indicatrix applied with Tissot's indicatrix displays all kinds of distortions at the given point (Figure 3).

Flexion can be expressively depicted by drawing the osculating circles of the mapped family of lines (geodesics) passing through the examined point. The radius $r$ of the osculating circle in a unit scale expressed in terms of flexion and linear scale using equation (9) is:

$$
r=\frac{1}{\kappa}=\frac{l}{f}
$$

where the units of $f$ and the map coordinate-system must be agreed.

Let the mapped radius of the enlarged pre-image of the Tissot's indicatrix correspond to $q$ distance on the reference surface, that is, $q$ is the radius of the empty red circles on Figure 3. Then, if an arc length $2 l q$ in a unit scale from the osculating circle of the mapped geodesic line is drawn, the central angle of the arc turns out to be in direct proportion to the depicted flexion $f$. Flexion can be read off the figure using a protractor. If the central angle of the arc is $\Delta \alpha^{\prime}$, then $f=\Delta \alpha^{\prime} /(2 q)$.

The illustration represents skewness by the placement of the arc sections. Assuming that $s$ is constant along the geodesic line, the linear scale will be a linear function of the distance $t$ on the reference surface. It follows from equation (6) that $l=l_{0}(1+s t)$, where $l_{0}$ is the linear scale in the examined point. It transpires that the mapped length of the finite distance $q$ in unit scale is:

$$
\int_{0}^{q}\left(l_{0}+l_{0} s t\right) \mathrm{d} t=l_{0} q\left(1+\frac{s q}{2}\right)
$$

where $s$ and $q$ must use the same units of measurement. The equation (18) results only in a displacement of the arc section with $l_{0} s q^{2} / 2$ - i.e. proportionally to the depicted distortion - but its summarized length in both directions remains:

$$
\int_{-q}^{q}\left(l_{0}+l_{0} s t\right) d t=2 l_{0} q
$$




$$
\begin{gathered}
\frac{\mathrm{d}^{2} x}{\mathrm{~d} t^{2}}=-\frac{\partial x}{\partial \varphi} \frac{\tan \varphi \sin ^{2} \alpha}{R^{2}}+\frac{\partial x}{\partial \lambda} \frac{2 \tan \varphi \sin \alpha \cos \alpha}{R^{2} \cos \varphi}+ \\
+\frac{\partial^{2} x}{\partial \varphi^{2}} \frac{\cos ^{2} \alpha}{R^{2}}+\frac{\partial^{2} x}{\partial \lambda^{2}} \frac{\sin ^{2} \alpha}{R^{2} \cos ^{2} \varphi}+2 \frac{\partial^{2} x}{\partial \varphi \partial \lambda} \frac{\cos \alpha \sin \alpha}{R^{2} \cos \varphi} \\
\frac{\mathrm{d}^{2} y}{\mathrm{~d} t^{2}}=-\frac{\partial y}{\partial \varphi} \frac{\tan \varphi \sin ^{2} \alpha}{R^{2}}+\frac{\partial y}{\partial \lambda} \frac{2 \tan \varphi \sin \alpha \cos \alpha}{R^{2} \cos \varphi}+ \\
+\frac{\partial^{2} y}{\partial \varphi^{2}} \frac{\cos ^{2} \alpha}{R^{2}}+\frac{\partial^{2} y}{\partial \lambda^{2}} \frac{\sin ^{2} \alpha}{R^{2} \cos ^{2} \varphi}+2 \frac{\partial^{2} y}{\partial \varphi \partial \lambda} \frac{\cos \alpha \sin \alpha}{R^{2} \cos \varphi}
\end{gathered}
$$

gdje su parcijalne derivacije poznate funkcije od $\varphi$ i $\lambda$.

Goldberg i Gott (2007) opisali su mnogo složeniju metodu računanja koja zahtijeva formule inverzne projekcije i računanje Christoffelovih simbola. Za razliku od toga, parcijalne derivacije $u$ ovdje opisanim formulama mogu se aproksimirati numeričkim metodama i jednostavno primijeniti u računanju.

Jednostavan način za sagledavanje te vrste deformacija dobije se ako su formule za projekciju dva puta diferencijabilne i tada vrijedi:

$$
\begin{aligned}
& f(\varphi, \lambda, \alpha)=-f(\varphi, \lambda, \alpha+\pi) \text { i } \\
& s(\varphi, \lambda, \alpha)=-s(\varphi, \lambda, \alpha+\pi) \quad(15)
\end{aligned}
$$

Primjenom formula (8) i (10) može se dobiti odnos između fleksije, asimetrije i druge derivacije formula projekcije:

$$
l \sqrt{f^{2}+s^{2}}=\sqrt{\left(\frac{d^{2} x}{d t^{2}}\right)^{2}+\left(\frac{d^{2} y}{d t^{2}}\right)^{2}}
$$

Ta je formula vizualizirana na slici 2 upotrebom oznake

$$
\mathbf{l}=\left(\frac{\mathrm{d} x}{\mathrm{~d} t} ; \frac{\mathrm{d} y}{\mathrm{~d} t}\right)
$$

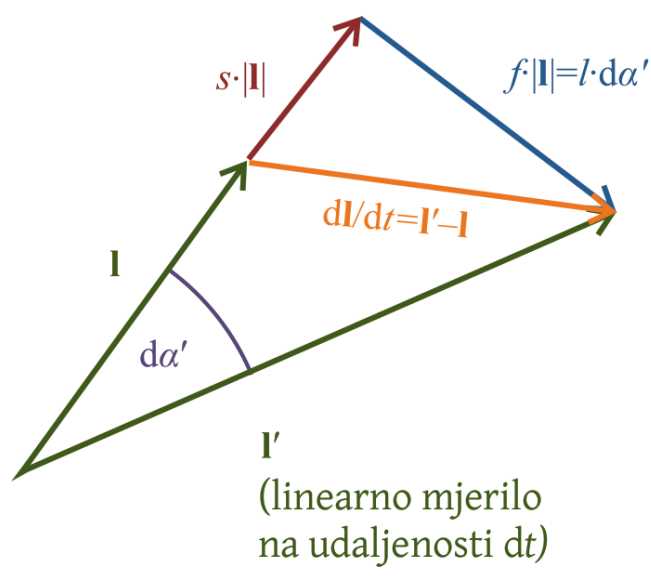

Slika 2 Opis značenja fleksije i asimetrije gdje je zbroj kvadrata fleksije i asimetrije jednak kvadratu druge derivacije projekcije (vektor označen narančasto, normalizirano u odnosu na linearno mjerilo).

Važno svojstvo tih mjera je da su invarijantne na transformacije po sličnosti.

Linije i točke bez distorzije mogu se također interpretirati s pomoću fleksije i asimetrije:

- Kod ekvidistantnih, ekvivalentnih i konformnih cilindričnih projekcija na ekvatoru nema fleksije ni asimetrije.

- Nema fleksije ni asimetrije u polovima kod ekvidistantnih, ekvivalentnih ili konformnih azimutnih projekcija.

- Među konusnim projekcijama s jednom standardnom paralelom, ekvidistantne i ekvivalentne s polom-linijom te konformne s polom-točkom nema fleksije ni asimetrije uzduž standardne paralele. Međutim, vjerojatno nema paralela bez fleksije i asimetrije kod ekvidistantnih i ekvivalentnih konusnih projekcija s polom-točkom ili s dvjema standardnim paralelama.

\section{Vizualizacija fleksije i asimetrije}

Iako su Goldberg i Gott (2007) razvili metodu vizualizacije za prikaz fleksije i asimetrije, oni su to napravili preslikavanjem konačnih oblika pokazujući učinak tih distorzija na neizravan način. Indikatrisa deformacija, kao što je prikazano u nastavku, omogućava izravnu vizualizaciju. Primijenjena zajedno s Tissotovom indikatrisom prikazuje sve vrste distorzija u zadanoj točki (slika 3).

Fleksija se može izražajno prikazati crtanjem oskulacijskih kružnica uz familiju preslikanih geodetskih linija koje prolaze točkom koju istražujemo. Polumjer $r$ oskulacijske kružnice $u$ jediničnom mjerilu izražen $s$ pomoću fleksije i linearnog mjerila uz upotrebu jednadžbe (9) glasi:

$$
r=\frac{1}{\kappa}=\frac{l}{f}
$$

gdje se moraju slagati jedinice $f \mathrm{i}$ koordinatnog sustava karte.

Neka preslikani polumjer povećanog originala Tissotove indikatrise odgovara udaljenosti $q$ na referentnoj plohi, tj. $q$ je polumjer crvenih kružnica na slici 3. Tada, ako je nacrtan luk duljine $2 l q u$ jedinicama oskulacione kružnice preslikane geodetske linije, središnji kut luka treba biti proporcionalan prikazanoj fleksiji f. Fleksija se može pročitati sa slike s pomoću kutomjera. Ako je središnji kut luka $\Delta \alpha^{\prime}$, tada je $f=\Delta \alpha^{\prime} /(2 q)$.

Ilustracija prikazuje asimetriju postavljanjem dijelova lukova. Uz pretpostavku da je $s$ konstantno uzduž geodetske linije, linearno mjerilo bit će linearna funkcija 


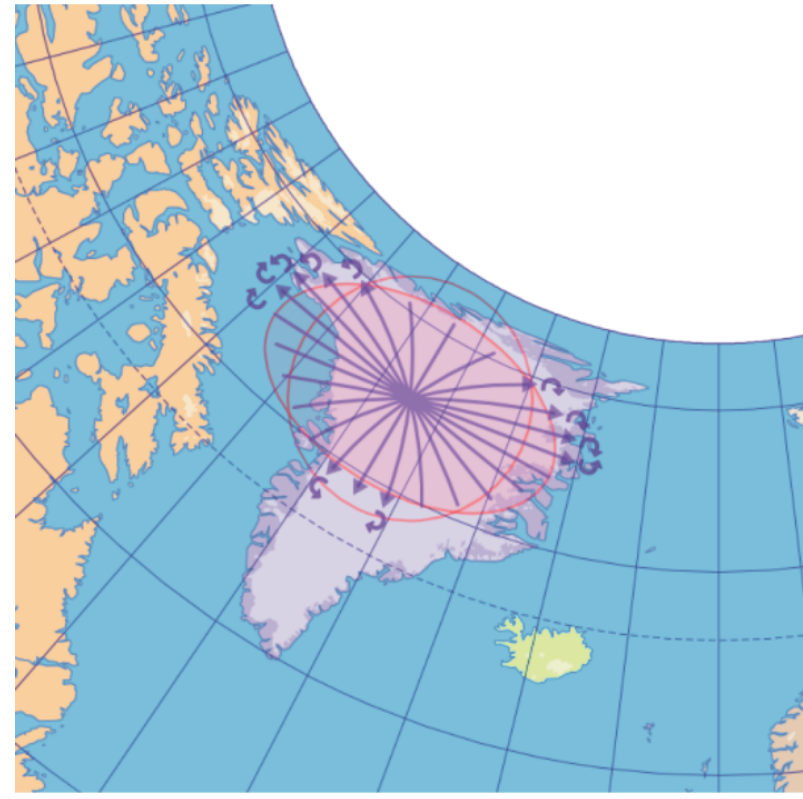

a) In equal-area (Albers) projection a) Ekvivalentna (Albersova) projekcija

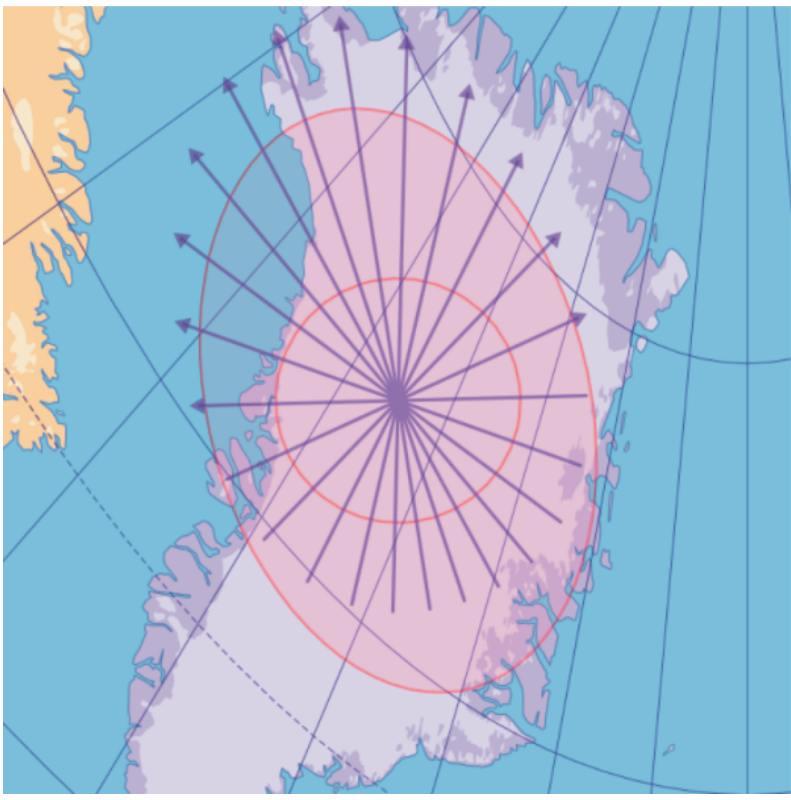

c) In oblique gnomonic projection c) Kosa gnomonska projekcija

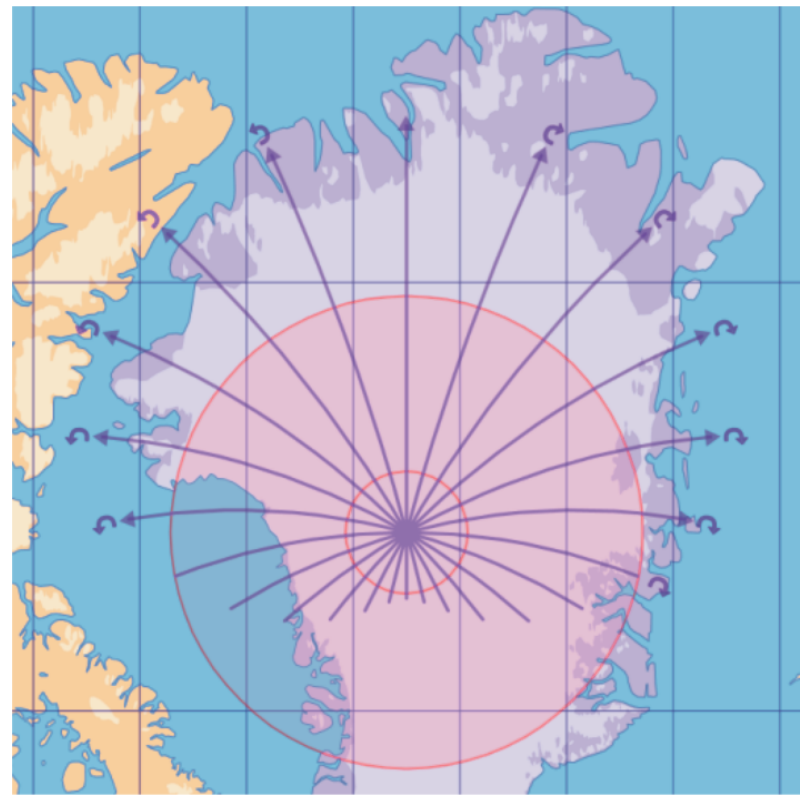

b) In conformal (Mercator) projection b) Konformna (Mercatorova) projekcija

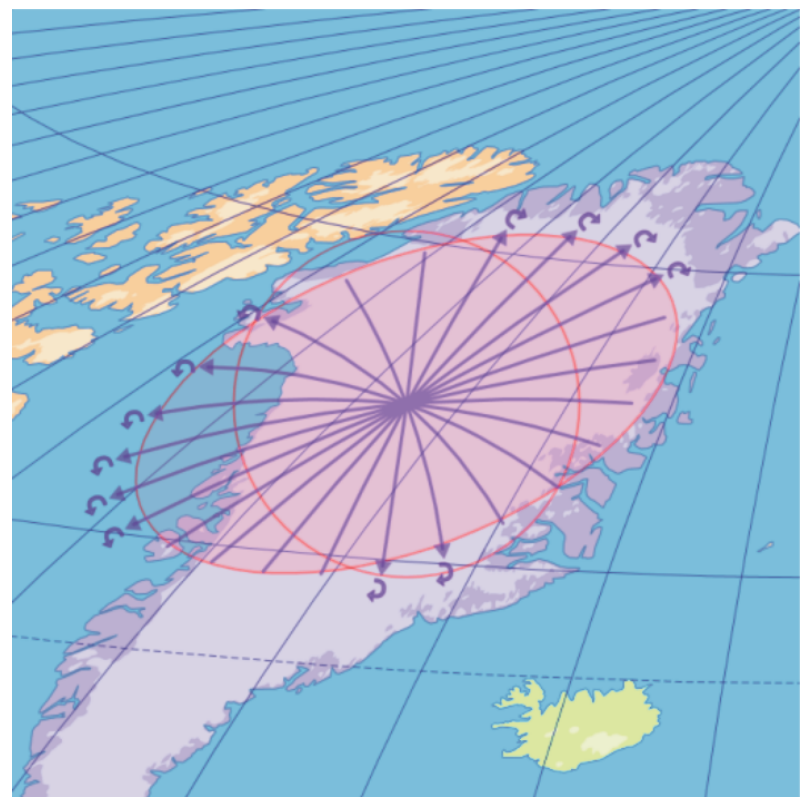

d) In modified azimuthal (Aitoff) projection d) Modificirana azimutna (Aitovljeva) projekcija

Fig. 3 Deformation indicatrix and Tissot's indicatrix at a point in Greenland $(q=R / 10=637.1 \mathrm{~km})$

Slika 3. Indikatrisa deformacija i Tissotova indikatrisa u točki na Greenlandu $q=R / 10=637,1 \mathrm{~km}$ )

Since $f$ and $s$ fluctuate rapidly depending on azimuth it is advisable to draw these arcs densely, even up to every $15^{\circ}$, if the map scale makes it possible. $f$ and $s$ are hard to see with the naked eye in less distorted parts of generally used projections. It is therefore necessary to exaggerate the direction of flexion and skewness with arrowheads, omitting the arrows if there is no distortion (Figure 4).
All the formulas above assume that projection formulas are twice differentiable. This is not the case at certain lines of some projections. Particular attention must be paid to these lines when drawing the deformation indicatrix. Discontinuity in the second derivative does not necessarily result in cusps. These identities do not hold, for example, at the Equator of interrupted pseudo-cylindrical projections and at the mid-meridian 
udaljenosti $t$ na referentnoj plohi. Iz jednadžbe (6) slijedi da je $l=l_{0}(1+s t)$, gdje je $l_{0}$ linearno mjerilo u točki koju istražujemo. Odatle slijedi da je duljina preslikane konačne udaljenosti $q$ u jedinicama mjerila jednaka:

$$
\int^{q}\left(l_{0}+l_{0} s t\right) \mathrm{d} t=l_{0} q\left(1+\frac{s q}{2}\right)
$$

gdje $s$ i $q$ moraju biti $u$ istim mjernim jedinicama. Jednadžba (18) ima za posljedicu samo pomak dijela luka za $l_{0} s q^{2} / 2$, tj. proporcionalno prikazanoj distorziji, a zbroj duljina u oba smjera je:

$$
\int_{-q}^{q}\left(l_{0}+l_{0} s t\right) \mathrm{d} t=2 l_{0} q
$$

Budući da se fi s brzo mijenjaju u ovisnosti o azimutu $\alpha$, preporučljivo je crtati te lukove dovoljno gusto (na svakih $15^{\circ}$ ) ako to dopušta mjerilo karte. $f$ i s je teško vidjeti prostim okom na manje distorziranim dijelovima projekcija. Zbog toga je nužno jače naglasiti smjer fleksije i asimetrije s pomoću strelica, odnosno bez strelica ako distorzije nema (slika 4).

U svim navedenim formulama pretpostavljeno je da je projekcija dva puta diferencijabilna. To nije slučaj uzduž pojedinih linija u nekim projekcijama. Tim linijama treba posvetiti posebnu pozornost pri crtanju indikatrisa. Diskontinuitet drugih derivacija ne mora nužno rezultirati u šiljcima. Upotrijebljeni identiteti ne moraju vrijediti npr. na ekvatoru kod prekinutih pseudocilindričnih projekcija i na srednjem meridijanu projekcije Baranyi IV. U tim slučajevima potrebno je posebno izračunati granične vrijednosti odozgo i odozdo.
Izvornu Goldberg-Gottovu indikatrisu, prikazanu u članku Goldberga i Gotta (2007), indikatrisa deformacija poboljšava u sljedećem:

- Nema potrebe za upotrebom konačnih objekata za vrijeme računanja, indikatrisa deformacija odražava distorziju egzaktno $\mathrm{u}$ analiziranoj točki, a distorzije $\mathrm{u}$ susjednim točkama ne utječu na njezinu interpretaciju.

- Vrijednosti fleksije i asimetrije mogu se točno pročitati iz indikatrise deformacija.

- Nisu prikazane samo distorzije uzduž paralela i meridijana. S Goldbergovih slika čini se kao da nema asimetrije u uspravnoj ekvidistantnoj cilindričnoj projekciji (Plate Carrée) iako ona nestaje samo u izvjesnim smjerovima.

\section{Proširenje formula na rotacijski elipsoid}

Zemljin oblik može se aproksimirati ne samo sferom, nego i rotacijskim elipsoidom s većom poluosi A i prvim ekscentricitetom $e$. Zbog jasnoće velikim su grčkim slovima označene geodetska širina i dužina kad je riječ o rotacijskom elipsoidu. Uvedimo sljedeće oznake:

$$
\begin{gathered}
N(\Phi)=\frac{A}{\sqrt{1-e^{2} \sin ^{2} \Phi}} \\
M(\Phi)=\frac{A\left(1-e^{2}\right)}{\left(1-e^{2} \sin ^{2} \Phi\right)^{3 / 2}}
\end{gathered}
$$

Tada umjesto formula (2) linearno mjerilo postaje (Bugajevskij i Snyder 1995):

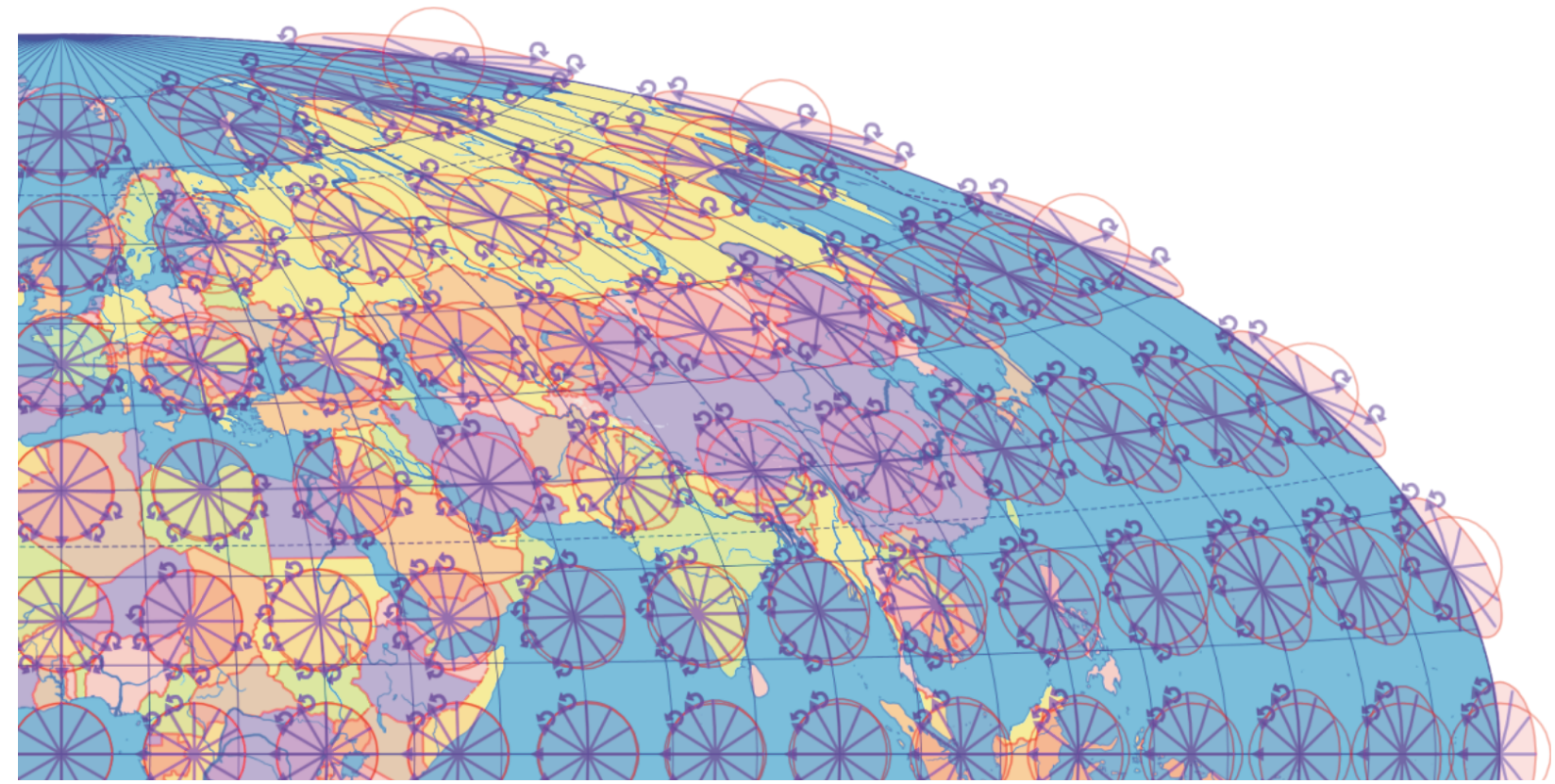

Fig. 4 Distorsion of the Hammer projection

Slika 4 Distorzija Hammerove projekcije 
of the Baranyi IV projection. In such cases, limits of the second derivative must be separately calculated from below and from above.

The deformation indicatrix improves upon the original Goldberg-Gott-indicatrix presented in the article (Goldberg \& Gott 2007):

- There is no need to use finite objects during the calculation, the deformation indicatrix reflects the distortion exactly at the analysed point, and the distortions at the neighbouring points do not influence its interpretation.

- The values of flexion and skewness can be read from the deformation indicatrix in a rigorous way.

- Not only distortion along parallels and meridians are represented. It seems, according to Goldberg's figures, that there is no skewness in the Plate Carrée projection, although it diminishes only in certain directions.

\section{Extending Formulas for the Ellipsoid of Revolution}

A sphere can approximate the figure of the Earth, and also an ellipsoid with semi-major axis $A$ and first eccentricity $e$. For clarity, capital Greek letters mark the latitude and longitude when applied to an ellipsoid of revolution. Let us introduce the following notations:

$$
\begin{gathered}
N(\Phi)=\frac{A}{\sqrt{1-e^{2} \sin ^{2} \Phi}} \\
M(\Phi)=\frac{A\left(1-e^{2}\right)}{\left(1-e^{2} \sin ^{2} \Phi\right)^{3 / 2}}
\end{gathered}
$$

Then instead of formula (2) the linear scale becomes (Bugajevskij \& Snyder 1995):

$$
\begin{gathered}
l^{2}=\left[\left(\frac{\partial x}{\partial \Phi}\right)^{2}+\left(\frac{\partial y}{\partial \Phi}\right)^{2}\right] \frac{\cos ^{2} \alpha}{M^{2}(\Phi)}+ \\
+\left[\left(\frac{\partial x}{\partial \Lambda}\right)^{2}+\left(\frac{\partial y}{\partial \Lambda}\right)^{2}\right] \frac{\sin ^{2} \alpha}{N^{2}(\Phi) \cos ^{2} \Phi}+ \\
+2\left[\frac{\partial x}{\partial \Phi} \frac{\partial x}{\partial \Lambda}+\frac{\partial y}{\partial \Phi} \frac{\partial y}{\partial \Lambda}\right] \frac{\sin \alpha \cos \alpha}{M(\Phi) N(\Phi) \cos \Phi}
\end{gathered}
$$

Flexion and skewness can be defined for the sphere and for the ellipsoid of revolution as a reference frame. Formulas (6)-(10) do not change, but the ellipsoidal formula (22) should be substituted for $l$. However, instead of the spherical differentials (11)-(14), ellipsoidal quantities are derived after Legendre (1806) as follows:

$$
\frac{\mathrm{d} x}{\mathrm{~d} t}=\frac{\partial x}{\partial \Phi} \frac{\cos \alpha}{M(\Phi)}+\frac{\partial x}{\partial \Lambda} \frac{\sin \alpha}{N(\Phi) \cos \Phi}
$$

$$
\frac{\mathrm{d} y}{\mathrm{~d} t}=\frac{\partial y}{\partial \Phi} \frac{\cos \alpha}{M(\Phi)}+\frac{\partial y}{\partial \Lambda} \frac{\sin \alpha}{N(\Phi) \cos \Phi}
$$

$$
\begin{aligned}
& \frac{\mathrm{d}^{2} x}{\mathrm{~d} t^{2}}=-\frac{\partial x}{\partial \Phi} \frac{\left(1-e^{2}\right) \tan \Phi \sin ^{2} \alpha+3 e^{2} \cos ^{2} \alpha \sin \Phi \cos \Phi}{M^{2}(\Phi)\left(1-e^{2} \sin ^{2} \Phi\right)}+ \\
& +\frac{\partial x}{\partial \Lambda} \frac{2 \tan \Phi \sin \alpha \cos \alpha}{N^{2}(\Phi) \cos \Phi}+\frac{\partial^{2} x}{\partial \Phi^{2}} \frac{\cos ^{2} \alpha}{M^{2}(\Phi)}+ \\
& +\frac{\partial^{2} x}{\partial \Lambda^{2}} \frac{\sin ^{2} \alpha}{N^{2}(\Phi) \cos ^{2} \Phi}+2 \frac{\partial^{2} x}{\partial \Phi \partial \Lambda} \frac{\cos \alpha \sin \alpha}{M(\Phi) N(\Phi) \cos \Phi} \\
& \frac{\mathrm{d}^{2} y}{\mathrm{~d} t^{2}}=-\frac{\partial y}{\partial \Phi} \frac{\left(1-e^{2}\right) \tan \Phi \sin ^{2} \alpha+3 e^{2} \cos ^{2} \alpha \sin \Phi \cos \Phi}{M^{2}(\Phi)\left(1-e^{2} \sin ^{2} \Phi\right)}+ \\
& +\frac{\partial y}{\partial \Lambda} \frac{2 \tan \Phi \sin \alpha \cos \alpha}{N^{2}(\Phi) \cos \Phi}+\frac{\partial^{2} y}{\partial \Phi^{2}} \frac{\cos ^{2} \alpha}{M^{2}(\Phi)}+ \\
& +\frac{\partial^{2} y}{\partial \Lambda^{2}} \frac{\sin ^{2} \alpha}{N^{2}(\Phi) \cos ^{2} \Phi}+2 \frac{\partial^{2} y}{\partial \Phi \partial \Lambda} \frac{\cos \alpha \sin \alpha}{M(\Phi) N(\Phi) \cos \Phi}
\end{aligned}
$$

Any other formula and identity stated in this article are also valid for a projection using an ellipsoid of revolution, as they do not refer to spherical quantities.

\section{Overall Flexion and Skewness over a Finite Surface}

Gott, Mugnolo \& Colley (2007) showed that the average of projection distortion should be calculated using statistical quantities - e.g. standard deviation, expected value.

As a statistical population, the expected values of flexion and skewness considered as stochastic quantities are 0 at any point of twice differentiable projections as vector-valued functions, which is the consequence of (15). At the same time, it makes sense to examine the standard deviation of the statistical population, since the deviation from the expected value is also the deviation from the state without distortion. Because flexion and skewness are continuous quantities, their standard deviations stochastically converge to the following surface integrals (note that the standard deviation is equal to the second algebraic moment, as the expected value is zero):

$$
\begin{aligned}
& E_{f}=\sqrt{\frac{1}{S} \iint_{S} \frac{1}{2 \pi} \oint f^{2} \mathrm{~d} \alpha \mathrm{d} S} \\
& E_{S}=\sqrt{\frac{1}{S} \iint_{S} \frac{1}{2 \pi} \oint s^{2} \mathrm{~d} \alpha \mathrm{d} S}
\end{aligned}
$$

where $S$ is the examined area on the reference surface. 


$$
\begin{array}{r}
l^{2}=\left[\left(\frac{\partial x}{\partial \Phi}\right)^{2}+\left(\frac{\partial y}{\partial \Phi}\right)^{2}\right] \frac{\cos ^{2} \alpha}{M^{2}(\Phi)}+ \\
+\left[\left(\frac{\partial x}{\partial \Lambda}\right)^{2}+\left(\frac{\partial y}{\partial \Lambda}\right)^{2}\right] \frac{\sin ^{2} \alpha}{N^{2}(\Phi) \cos ^{2} \Phi}+ \\
+2\left[\frac{\partial x}{\partial \Phi} \frac{\partial x}{\partial \Lambda}+\frac{\partial y}{\partial \Phi} \frac{\partial y}{\partial \Lambda}\right] \frac{\sin \alpha \cos \alpha}{M(\Phi) N(\Phi) \cos \Phi}
\end{array}
$$

Fleksija i asimetrija mogu se definirati ne samo za sferu, nego i za rotacijski elipsoid kao referentnu plohu. Formule (6) - (10) se ne mijenjaju, no elipsoidnu formulu (22) treba uvrstiti za l. Umjesto sfernih diferencijala (11) - (14) elipsoidne veličine izvedene su prema Legendreu (1806) kako slijedi:

$$
\begin{aligned}
& \frac{\mathrm{d} x}{\mathrm{~d} t}=\frac{\partial \mathrm{x}}{\partial \Phi} \frac{\cos \alpha}{M(\Phi)}+\frac{\partial x}{\partial \Lambda} \frac{\sin \alpha}{N(\Phi) \cos \Phi} \\
& \frac{\mathrm{d} y}{\mathrm{~d} t}=\frac{\partial y}{\partial \Phi} \frac{\cos \alpha}{M(\Phi)}+\frac{\partial y}{\partial \Lambda} \frac{\sin \alpha}{N(\Phi) \cos \Phi}
\end{aligned}
$$

$$
\frac{\mathrm{d}^{2} x}{\mathrm{~d} t^{2}}=-\frac{\partial x}{\partial \Phi} \frac{\left(1-e^{2}\right) \tan \Phi \sin ^{2} \alpha+3 e^{2} \cos ^{2} \alpha \sin \Phi \cos \Phi}{M^{2}(\Phi)\left(1-e^{2} \sin ^{2} \Phi\right)}+
$$$$
+\frac{\partial x}{\partial \Lambda} \frac{2 \tan \Phi \sin \alpha \cos \alpha}{N^{2}(\Phi) \cos \Phi}+\frac{\partial^{2} x}{\partial \Phi^{2}} \frac{\cos ^{2} \alpha}{M^{2}(\Phi)}+
$$$$
+\frac{\partial^{2} x}{\partial \Lambda^{2}} \frac{\sin ^{2} \alpha}{N^{2}(\Phi) \cos ^{2} \Phi}+2 \frac{\partial^{2} x}{\partial \Phi \partial \Lambda} \frac{\cos \alpha \sin \alpha}{M(\Phi) N(\Phi) \cos \Phi}
$$

$$
\frac{\mathrm{d}^{2} y}{\mathrm{~d} t^{2}}=-\frac{\partial y}{\partial \Phi} \frac{\left(1-e^{2}\right) \tan \Phi \sin ^{2} \alpha+3 e^{2} \cos ^{2} \alpha \sin \Phi \cos \Phi}{M^{2}(\Phi)\left(1-e^{2} \sin ^{2} \Phi\right)}+
$$$$
+\frac{\partial y}{\partial \Lambda} \frac{2 \tan \Phi \sin \alpha \cos \alpha}{N^{2}(\Phi) \cos \Phi}+\frac{\partial^{2} y}{\partial \Phi^{2}} \frac{\cos ^{2} \alpha}{M^{2}(\Phi)}+
$$$$
+\frac{\partial^{2} y}{\partial \Lambda^{2}} \frac{\sin ^{2} \alpha}{N^{2}(\Phi) \cos ^{2} \Phi}+2 \frac{\partial^{2} y}{\partial \Phi \partial \Lambda} \frac{\cos \alpha \sin \alpha}{M(\Phi) N(\Phi) \cos \Phi}
$$

Sve druge formule i identiteti u ovom članku vrijede i za projekcije rotacijskog elipsoida jer se ne odnose na sferne veličine.

\section{Prosječna fleksija i asimetrija na konačnom području neke plohe}

Gott, Mugnolo i Colley (2007) pokazali su da se srednja distorzija projekcije treba izračunati upotrebom statističkih veličina, npr. standardna devijacija, očekivana vrijednost.
Kao statistička populacija, očekivane vrijednosti fleksije i asimetrije promatrane kao statističke vrijednosti su 0 u bilo kojoj točki dva puta diferencijabilne projekcije, što je posljedica relacije (15). U isto vrijeme ima smisla ispitati standardnu devijaciju statističke populacije jer je odstupanje od očekivane vrijednosti također odstupanje od stanja bez distorzije. Budući da su fleksija i asimetrija neprekidne veličine, njihove standardne devijacije stohastički konvergiraju prema sljedećim plošnim integralima (uočimo da je standardna devijacija jednaka drugom algebarskom momentu kad je očekivana vrijednost nula):

$$
\begin{aligned}
& E_{f}=\sqrt{\frac{1}{S} \iint_{S} \frac{1}{2 \pi} \oint f^{2} \mathrm{~d} \alpha \mathrm{d} S} \\
& E_{S}=\sqrt{\frac{1}{S} \iint_{S} \frac{1}{2 \pi} \oint s^{2} \mathrm{~d} \alpha \mathrm{d} S}
\end{aligned}
$$

gdje je $S$ područje na zadanoj referentnoj plohi.

Konformne projekcije promatrane kao preslikavanja u kompleksnoj analizi su holomorfne - veličina i smjer njihovih diferencijala (kao vektor) ovisi samo o položaju, a ne i o smjeru diferenciranja. Zbog toga postoji smjer $\alpha_{0}$ u svakoj točki konformne projekcije koji odgovara smjeru gradijenta linearnog mjerila na referentnoj plohi i za koji je $s(\alpha)=s\left(\alpha_{0}\right) \cos \left(\alpha-\alpha_{0}\right)$ i $f(\alpha)=-s\left(\alpha_{0}\right) \sin \left(\alpha-\alpha_{0}\right)$. Prema tome, za konformne projekcije je:

$$
\frac{1}{2 \pi} \oint f^{2} \mathrm{~d} \alpha=\frac{1}{2 \pi} \oint s^{2} \mathrm{~d} \alpha=\frac{s^{2}\left(\alpha_{0}\right)}{2}
$$

Bajeva (1987) je pokazala da su površinske i kutne distorzije tipa Kavrajskoga, t. $\ln ^{2} a b$ i $\ln ^{2} b / a$, jednake u svakoj točki ekvidistantnih projekcija. Ona je istaknula da ta jednakost za posebnu klasu projekcija sugerira da su površinske i kutne distorzije tipa Kavrajskoga mjerene $u$ istom mjerilu, stoga njihova težinska sredina ima smisla. Formula (29) pokazuje analogni odnos između fleksije i asimetrije - te su veličine jednake u bilo kojoj točki posebne klase projekcija (u ovom slučaju konformnih). Dakle, može se vidjeti da su, upravo kao kod površinskih i kutnih distorzija, fleksija i asimetrija komplementarne i mogu se zbrojiti dajući ukupnu neafinu distorziju:

$$
E_{G}=\sqrt{\frac{1}{S} \iint_{S} \frac{1}{2 \pi} \oint \frac{f^{2}+s^{2}}{2} \mathrm{~d} \alpha \mathrm{d} S}
$$

koja se može pojednostaviti uvrštavanjem jednadžbe (16).

Analitički izraz za navedene integrale može biti složen pa se stoga predlažu numeričke metode za njihovo računanje. Zbog njegove bolje konvergencije preporuča 
Conformal projections considered as complex mappings are holomorphic; therefore, the magnitude and the direction of their differentials (as a vector) depend only on the location, and not on the direction of the differentiation. For this reason, a direction $\alpha_{0}$ at any point of conformal projections corresponds to the direction of the gradient of the linear scale on the reference frame for which $s(\alpha)=s\left(\alpha_{0}\right) \cos \left(\alpha-\alpha_{0}\right)$ and $f(\alpha)=-s\left(\alpha_{0}\right) \sin \left(\alpha-\alpha_{0}\right)$. It is clear, then, that in conformal projections:

$$
\frac{1}{2 \pi} \oint f^{2} \mathrm{~d} \alpha=\frac{1}{2 \pi} \oint s^{2} \mathrm{~d} \alpha=\frac{s^{2}\left(\alpha_{0}\right)}{2}
$$

Bajeva (1987) showed that areal and angular distortions of Kavrajskij's type - i. e. $\ln ^{2} a b$ and $\ln ^{2} b / a-$ are equal at any point of equidistant projections. She pointed out that this equality in a specific class of map projection suggests that areal and angular distortions of Kavrajskij's type are measured on the same scale; their weighted average is a meaningful quantity. Formula (29) shows an analogous relationship between flexion and skewness: These quantities are the same at any point in a special class of projections (now conformal). Thus, it can be seen that, just like areal and angular distortions, flexion and skewness are complementary, and they can be summarized giving the overall non-affine distortion:

$$
E_{G}=\sqrt{\frac{1}{S} \iint_{S} \frac{1}{2 \pi} \oint \frac{f^{2}+s^{2}}{2} \mathrm{~d} \alpha \mathrm{d} S}
$$

which can be simplified by substituting equation (16).

The analytic expression of the integrals above can be difficult, so numerical methods are suggested for their calculation. Simpson's rule is recommended due to its preferable convergence, which is described in Kerkovits
(2017) for an irregular spherical polygon, but it can be derived in a similar manner for polygons of any rotational surface, such as the ellipsoid of revolution.

The calculation method proposed here is now deterministic, and it is not necessary to generate random points. Instead of the absolute value suggested by Goldberg, the formulas are squared; it can thus be differentiated so that effectively converging numerical methods can be used. The use of standard deviation as a measurement of distortion is consistent with the distortion criteria already applied in the map projection theory, as they can be interpreted as the second algebraic (Airy 1861) or geometric (Kavrajskij 1934) moment of the traditional measures about 1 .

Since the average distortion is interpreted as the standard deviation of flexion and skewness, it also has a dimension that is 1 / distance. Consequently, it cannot be summed up with standard measurements of distortion such as the dimensionless terms of the Airy-Kavrajskij criterion.

\section{Conclusion}

The measurements introduced in the article by Goldberg \& Gott are indeed useful and provide many added values compared to traditional theories, but the calculation method they provided was difficult to understand and execute. In this paper, simpler formulas have been provided and the definition has been extended to include the surface of an ellipsoid of revolution. It was also found that these kinds of distortion have a dimension and unit of measurement. By extending Tissot's indicatrix, a visualisation method was developed to show the distribution of flexion and skewness in the given projection, both expressively and in a measurable way.

\section{Acknowledgements}

The author would like to express his special thank to Miljenko Lapaine for translating the paper to Croatian. He also thanks Gercsák Gábor and Györffy János for their helpful comments on an earlier version of the manuscript.

\section{Zahvala}

Autor izražava posebnu zahvalnost Miljenku Lapaineu za prijevod članka na hrvatski jezik. Također zahvaljuje Gáboru Gercsáku i Jánosu Györffyu na korisnim komentarima na prethodnu verziju rukopisa. 
se Simpsonovo pravilo, što je opisao Kerkovits (2017) za nepravilan sferni poligon, no ono se može izvesti na sličan način za bilo koju rotacijsku plohu, poput rotacijskog elipsoida.

Ovdje predložena metoda računanja je deterministička i nije nužno generirati slučajne točke. Umjesto apsolutne vrijednosti, koju je predložio Goldberg, formule su kvadrirane. Prema tome mogu se diferencirati tako da se upotrijebe učinkovite konvergirajuće numeričke metode. Upotreba standardne devijacije kao mjere distorzije konzistentna je s kriterijima za distorziju koji su već primjenjivani u teoriji kartografskih projekcija, bilo da su interpretirani kao drugi algebarski (Airy 1861) ili geometrijski (Kavrajskij 1934) moment tradicionalne mjere oko 1.

Budući da je srednja distorzija interpretirana kao standardna devijacija fleksije i asimetrije, ona također ima dimenziju 1/udaljenost. Prema tome, ne može se zbrojiti sa standardnim mjerama distorzije kao što su bezdimenzijski članovi kriterija Airy-Kavrajskoga.

\section{Zaključak}

Mjerenja uvedena u članku Goldberga i Gotta zaista su korisna i omogućavaju mnogo dodadnih vrijednosti $\mathrm{u}$ usporedbi s tradicionalnim teorijama, no njihovu metodu računanja teško je razumjeti i provesti. U ovome radu dane su jednostavnije formule, a definicija je proširena na plohu rotacijskog elipsoida. Nadalje, uočeno je da te mjere distorzije imaju dimenziju i nađenu mjernu jedinicu. Proširenjem Tissotove indikatrise, razvijena je metoda vizualizacije kako bi se pokazala razdioba fleksije i asimetrije $u$ danoj projekciji i to izražajno i mjerljivo.

\section{References / Literatura}

Airy GB (1861) Explanation of a projection by balance of errors for maps applying to a very large extent of the earth's surface; and comparison of this projection with other projections. The London, Edinburgh, and Dublin Philosophical Magazine and Journal of Science 22/149, 409-421

Albinus HJ (1981) Anmerkungen und Kritik zur Entfernungsverzerrung. Kartographische Nachrichten 31/5, 179-183

[Bajeva] Баева ЕЮ (1987) Критерии оценки достоинства картографических проекций, исползуемых для составления карт Мира. Геодезия и аэрофотосъёмка 3, 109-112

Bugajevskij LM, Snyder JP (1995) Map Projections - A Reference Manual. Taylor \& Francis, London

Canters F (2002) Small-scale map projection design. Taylor \& Francis

Fisher I, Miller OM (1944) World maps and globes. Essential Books, New York

Goldberg DM, Gott IIIJR (2007) Flexion and skewness in map projections of the Earth. Cartographica: The International Journal for Geographic Information and Geovisualization 42/4, 297-318. doi: 10.3138/carto.42.4.297

Gott III JR, Mugnolo C, Colley WN (2007) Map Projections Minimizing Distance Errors. Cartographica: The International Journal for Geographic Information and Geovisualization 42/3, 219-234. doi: 10.3138/carto.42.3.219

[Kavrajskij] Каврайский ВВ (1934): Математическая картография. Редбаза Госкартотреста, Москва-Ленинград

Kerkovits K (2017) Vorteilhafteste flächentreue Kegelentwürfe für unregelmäßig begrenzte Gebiete. Kartographische Nachrichten $67 / 3,122-128$

Laskowski P (1997) The distortion spectrum. Cartographica: The International Journal for Geographic Information and Geovisualization 34/3

Legendre A (1806) Analyse des triangles tracées sur la surface d'un sphéroide. Mémoires de l'Institut National de France. Vol. 1, 130-161

Mulcahy KA, Clarke KC (2001) Symbolization of Map Projection Distortion: A Review. Cartography and Geographic Information Science 28/3, 167-182. doi: 10.1559/152304001782153044

Peters AB (1975) Wie man unsere Weltkarten der Erde ähnlicher machen kann. Kartographische Nachrichten 25/5, 173-183

Snyder JP (1987) Map projections - A working manual. Vol. 1395. US Government Printing Office. url: http://pubs.er.usgs.gov/publication/pp1395

Stoker JJ (1989) Differential Geometry. John Wiley \& Sons, Hoboken, New Jersey

Tissot A (1878) Mémoire sur la représentation des surfaces et les projections des cartes géographiques. Nouvelles annales de mathématiques, journal des candidats aux écoles polytechnique et normale 17, 145-163

Tobler WR (1964) Geographical coordinate computations. Part II. Finite map projection distortions. Defense Technical Information Center, Ft. Belvoir 